\title{
Solidaritas Anarkisme Suporter Bola PSIM DAN PSS
}

\author{
Tera Puspita Werdiyanti \\ Prodi Sosiologi, Universitas Wisya Mataram \\ E-mail : terawerdiyanti20@gmail.com \\ As Martadani Noor \\ Prodi Sosiologi, Universitas Wisya Mataram \\ E-mail : asmartadani@gmail.com \\ Paharizal \\ Prodi Sosiologi, Universitas Wisya Mataram \\ E-mail : rizalpaharizal@gmail.com
}

\begin{abstract}
This research is located in Sleman, Yogyakarta. This research was conducted when researcher saw the solidarity of anarchism of football supporters. Factors related to the solidarity of anarchism of football supporters and the empowerment of football supporters, especially with PSIM and PSS. This research wants to describe more clearly how the solidarity of anarchism is, the factors associated with solidarity of anarchism and the empowerment of suporter in PSIM and PSS football clubs. This research was conducted with a qualitative descriptive research method. Data was collected by Snow Ball sampling until the data was at its saturation point. This method was chosen because the number of actors is large so it could gets more accurate data. The results obtained in the solidarity of football supporters anarchism prove that there are improvements from the supporters. Then the factors related to the solidarity of anarchism are still trying to become supporters who are more loved by the community and the empowerment of PSIM and PSS football supporters has not received training from any party.
\end{abstract}

Keywords : Anarchisme Solidarity, Football Fans, PSIM and PSS.

\section{Pendahuluan.}

Sepak bola adalah olahraga yang cukup populer dan digemari di seluruh dunia. Popularitas sepak bola semakin meningkat dengan peningkatan teknologi dan perkembangan zaman, dan selalu mendapat penggemar baru. Keberadaan sepak bola sendiri sudah ada sejak abad ke-2 dan ke-3 sebelum Masehi di Cina pada masa Dinasti Han dengan nama tsu chiu, masyarakat menggiring bola kulit dengan menendangnya ke jaring kecil. Permainan serupa juga dimainkan di Jepang dengan sebutan Kemari, Harpastum di Yunani dan Epyskiros di Romawi (Jezek, 2006).

Dalam penyatuan segala kebudayaan, sepak bola mampu menarik dan memobilisasi banyak orang sehingga berpengaruh dalam kehidupan masyarakat banyak. Salah satu fenomena yang muncul dalam realitas sepak bola adalah suporter. Kelompok suporter merupakan fenomena lebih lanjut dari legalisasi komunitas pendukung suatu kesebelasan. Oleh karena itu, munculah fanatisme dalam perilaku suporter sepak bola yang pada akhirnya memunculkan berbagai bentrokan antar suporter (Rahman, 2015)

Ramainya pertandingan sepak bola juga tidak lepas dari adanya suporter yang menonton langsung atau tidak di stadion. Suporter dianggap sebagai pemain ke-12 karena sepak bola dan suporter bagaikan sebuah mata uang yang mempunyai dua sisi yang tidak dapat dipisahkan. Istilah suporter cukup dekat kekerabatannya dengan kata penonton, namun istilah penonton maknanya akan lebih luas daripada suporter, artinya setiap suporter mestinya seorang penonton, sebaliknya tidak semua penonton itu adalah suporter. Masyarakat umum kadang memakai kedua istilah ini bertukartukar, karena susah membedakannya untuk menyebut obyek yang sama dengan pilihan 
dua kata: suporter dan penonton. Suporter sering kita jumpai pada setiap pertandingan olahraga yang memberikan dukungan terhadap seseorang maupun tim dalam suatu pertandingan olahraga. Apalagi dalam pertandingan sepak bola, olahraga tersebut rasanya tidak lengkap bila suatu tim sepak bola tidak memiliki suporter. Kehadiran suporter sangat berpengaruh dalam setiap pertandingan dan tidak jarang kreatifitas suporter justru lebih menarik perhatian daripada pertandingan itu sendiri (Makruf, 2015).

Beberapa kasus anarkisme di Yogyakarta yaitu seperti diungkapkan oleh The Maident adanya gesekan sampai mengarah pada tawuran yang melibatkan pendukung PSIM di Jalan Wonosari, Sekarsuli, Berbah, Sleman (24/3/2016). Menurut mereka, kasus tersebut harus diusut oleh kepolisan supaya tidak terjadi lagi hal yang serupa. Melalui rilis dari The Maident yang diterima Tribun Jogja, Rabu (23/3/2016), Ketua The Maident Hari Prastowo berharap hal tersebut tidak kembali terulang. Hari sendiri menegaskan bahwa The Maident tidak terlibat sama sekali dalam peristiwa tawuran ini. Setelah pihak pengurus melakukan koordinasi internal dengan para anggota dan tak menemukan salah satu anggota yang terlibat dalam insiden tersebut. Setelah dilakukan pertemuan untuk menentukan sikap yang diambil. Tak lupa pihak The Maident menghimbau kepada seluruh suporter PSIM Yogyakarta untuk sama-sama menjaga kondusifitas serta tetap loyal dalam mendukung tim kebanggaan PSIM dalam kondisi apapun.

Laga divisi utama antara PSS Sleman vs PSIM Yogyakarta rusuh karena terjadi kericuhan dan belasan orang terluka. Laga digelar di stadion Maguwoharjo Sleman. Beberapa kali, ribuan suporter kedua tim saling lempar batu, botol dan adu jotos dalam jarak dekat. Petugas menyemprotkan gas air mata untuk menghalau suporter. Mereka berlarian menyelamatkan diri, tapi kembali lagi bentrok. Belasan suporter terluka dan langsung dilarikan untuk mendapat perawatan ala kadarnya di beberapa ruang di stadion. Sebagian di antaranya adalah remaja putri yang pingsan. Sejumlah suporter terlihat mengeluarkan darah di bagian kepalanya. Ada yang dilarikan dengan menggunakan ambulans. Laga sudah 'panas' sejak menit awal. Laga sempat dihentikan, tapi kemudian dilanjutkan. Bentrok terparah terjadi saat laga hampir selesai. Lagi-lagi hal ini demi menjaga kondusifitas Yogyakarta dan seluruh wilayah DIY pada umumnya (Raharjo, 2014).

Suporter divonis memperburuk citra sepak bola dan dianggap menjadi problem bangsa. Tindak kekerasan, kerusuhan, dan jatuhnya korban sampai prasarana baik luka, tewas, rusak dan terganggunya ketertiban merupakan pranata sosial sampai prasarana umum, merupakan citra buruk yang melekat pada suporter sepak bola Indonesia. Kerusuhan suporter yang terjadi di Indonesia sebenarnya bukan isu baru karena sejak lama sebenarnya sudah sering terjadi (Suyatna,2007:38). Beberapa waktu yang lalu terjadi kerusuhan suporter di wilayah Sleman. Komisi Disiplin (Komdis) PSSI berkunjung ke Yogyakarta untuk melakukan investigasi terhadap kasus penyerangan bus suporter PSCS Cilacapl. Ketua Komisi Disiplin (Komdis) PSSI Hinca Pandjaitan menjelaskan dari hasil pengumpulan data dan bukti di kepolisian baik di Polsek maupun di Polres Sleman, akhirnya dijatuhkan sanksi kepada PSS Sleman. Penyerangan terhadap bus PSCS Cilacap mengarah kepada suporter PSS Sleman yang menamakan diri BCS. Berdasarkan temuan fakta-fakta itu Komdis PSSI telah memutuskan untuk menjatuhkan sanksi kepada PSS berupa satu kali pertandingan tanpa penonton. Laga tersebut juga harus digelar di luar home base PSS Sleman dengan jarak minimal $100 \mathrm{~km}$.

BCS adalah salah satu kelompok suporter yang berasal dari Sleman, Kelompok yang bermarkas di tribun selatan MIS ( Maguwoharjo International Stadium ) ini mempunyai cara unik tersendiri untuk mendukung team kesayangannya PSS Sleman. Salah satunya, melakukan koreografi disasaat pertandingan sedang berlangsung. Pada umumnya anggota 
Brigata Curva Sud memakai sepatu dan berpakaian rapih. Saat PSS Sleman bermain suporter ini tak pernah berhenti bernyanyi selama $45 \times 2$ pertandingan. Loyalitas ini ditunjukan pada saat PSS main stadion selalu dipenuhi oleh para suporter. Dan BCS juga mempunyai slogan " No Ticket, No Game"(cangkallaxcorporation.blogspot.co.id ,2013)

adalah kolidaritas yang pada umumnya mempersatukan dan menyamakan perbedaan disekeliling kita pun, sudah mulai pudar. Solidaritas itu penting karena sangat mempengaruhi perubahan sosial budaya. Perubahan sosial yang mencakup sikap setiap orang dan kondisi suatu lingkungan yang didominasi oleh perbedaan, dan perbedaan budaya yang menyebabkan solidaritas itu sendiri hilang seiring berjalannya waktu, dari generasi ke generasi karena tidak diterapkan dalam kehidupan sehari-hari ketika menghadapi perbedaan. Menciptakan keadaan sosial yang teratur dan satu, merupakan tujuan dari solidaritas (Ariani, 2013).

Dalam buku yang berjudul "Sepak Bola Tanpa Batas" yang ditulis oleh Anung Handoko (2008) memaparkan bahwa solidaritas menjadi kuat karena individualis dan persaingan sosial yang ketat memberi dampak kepada konsep solidaritas dalam kelompok suporter bola. Solidaritas mereka menjadi kurang kuat, fanatisme mereka pun cenderung anarkisme. Suporter klub Indonesia sebenarnya bukan hanya melulu identik dengan aksi-aksi tak terpuji dan jadi cibiran masyarakat di luar pencinta sepak bola. Sejumlah barisan supoter nyatanya memang memiliki aksi kreatifitas yang mumpuni, tak jarang aksi kreatifitas mereka mengarah ke pemberdayaan ekonomi mandiri. Kisah soal bagaimana kreatifitas suporter PSS Sleman, BCS bahkan sudah jadi pembicaraan publik di Asia. BCS memiliki rekam jejak tak sembarangan dalam hal kreatifitas dan ekonomi mandiri. Tidak hanya BCS yang memiliki semangat membangun sepak bola nasional dengan aksi kreatifitas dan ekonomi mandiri, barisan suporter Semen Padang pun melakukan hal sama. Kreatifitas suporter
Semen Padang bisa kita lihat dari goresan mereka di cerita komik yang tertuang di akun Facebook dan Instagram, Carito Kabau Sirah. Komik bernada satir yang menunjukkan kegelisahan para suporter di kehidupan sehari-hari atau soal sepakbola nasional dituangkan dengan cara-cara menggelitik dan sangat kreatif. Barisan suporter Semen Padang yang tergabung dalam Carito Kabau Sirah ini memanfaatkan betul kemajuan teknologi di media sosial sebagai media penunjuk eksistensi dan menunjukkan identitas mereka sebagai suporter kreatif. Konsep berdiri di atas ekonomi sendiri (berdikari) diterapkan nyata oleh BCS. BCS tercatat membangun unitunit usaha seperti distro CSS Shop, CS Mart, CS Pegadaian (untuk membantu anggota yang kesulitan dana saat away) dan CS Magazine (Prasetyo, 2017).

Berdasarkan paparan dari latar belakang diatas, penelitian ini secara khusus ingin melihat seperti apa solidaritas yang terjalin antar suporter sepak bola PSIM dan PSS, terlebih adalah tentang perilaku anarkis yang kemudian disebut dengan solidaritas anarkis. Juga akan melihat faktor-faktor apa saja mempengaruhi terbentuknya solidaritas yang semacam itu dan upaya apa yang dilakukan untuk memberdayakan komunitas suporter ini.

\section{Metode.}

Berdasarkan masalah yang akan diteliti, maka jenis metode yang digunakan adalah metode penelitian kualitatif. Penelitian ini bersifat deskriptif yang berusaha mendapatkan fakta serta memberikan gambaran dari suatu peristiwa dalam kehidupan masyarakat, yang dalam hal ini adalah aspek sosiologis perilaku suporter bola. Jenis penelitian kualitatif ini dipilih karena sasaran atau objek penelitian dibatasi sehingga dapat digali sedalam mungkin serta dapat dihindari adanya pelebaran objek penelitian. Penelitian kualitatif adalah penelitian yang bermaksud untuk memahami fenomena tentang apa yang dialami oleh subyek penelitian, misalnya perilaku, persepsi, motivasi, tindakan, dll., secara holistic, dan dengan cara deskripsi dalam bentuk kata-kata dan 
bahasa, pada suatu konteks khusus yang alamiyah dan dengan memanfaatkan berbagai metode ilmiyah (Moelong. 2001)

\section{Hasil dan Pembahasan.}

\section{Sepak Bola dan Suporter Sepak Bola.}

Suporter sepak bola merupakan kerumunan di mana diartikan sebagai sejumlah orang yang berada pada tempat yang sama, adakalanya tidak saling mengenal, dan memiliki sifat yang peka terhadap stimulus (rangsangan) yang datang dari luar. (Soeprapto, 2010). Menurut Chols, kata ,suporter , berasal dari kata kerja (verb) dalam bahasa Inggris to support dan akhiran (suffict) -er. To support artinya mendukung, sedangkan akhiran -er menunjukkan pelaku. Suporter dapat diartikan sebagai orang yang memberikan suporter atau dukungan. (Chols dan Hassan 1988) Graham (1976) mengartikan suporter sebagai individu maupun kelompok yang hadir pada suatu pertandingan olahraga dengan tujuan menunjukkan dukungannya kepada salah satu tim yang bertanding dan merasa memiliki keterikatan dengan klub tersebut. Suporter ini biasanya memiliki rasa kecintaan yang lebih dibandingkan penonton biasa yang hadir dilapangan.

Adapun aspek-aspek dari motivasi menurut Huitt (1999) ada tiga yaitu :

a. Direction.

Adalah sesuatu yang menjadi arah atau tujuan individu untuk melakukan atau berpartisipasi dalam sesuatu hal.Terdapat lima hal didalamnya antara lain :

1. Menyadari kebutuhan-kebutuhan kita sebagai manusia (to become aware of our human needs);

2. Menyadari akan kemampuan diri (to become aware of the "possible self") yang dapat dalam bentuk visions dan dreams (Levenson dalam Huitt, 1999);

3. Membuat pilihan (the exercise of volition);

4. Menentukan tujuan (the setting of goals for the directions that have been choosen),

5. Membuat perencanaan belajar (to develop plans that can turn visions and goals

b. Energizing
Adanya kebutuhan untuk pengembangan diri dan selfdetermination. Kebutuhan-kebutuhan tersebut dapat ditingkatkan atau terhalang oleh konsep diri dan harga diri seseorang. Dengan kata lain, konsep diri dan harga diri seseorang dapat meningkatkan atau menghalangi pengembangan diri dan selfdetermination seseorang.

c. Persistence.

Ketahanan diri seseorang dalam melaksanakan komitmen awalnya. Persistensi merupakan subkomponen ketiga setelah direction dan energizing. Huitt (1999) lebih jauh menjelaskan bahwa persistensi dipengaruhi oleh karakteristik seseorang (tingkat motivasi berprestasi, harapan, tingkat harga diri, pengalaman kegagalan, dihargai karena usaha seseorang (atau being praised for effort rather than ability, dan lain sebagainya) (Handoko dan Andrianto, 2006).

\section{Perserikatan Sepak Bola Indonesia Mataram (PSIM)}

PSIM terbentuk tanggal 5 September 1929 dengan lahirnya organisasi sepak bola yang diberi nama Perserikatan Sepak Raga Mataram atau disingkat PSM. Nama Mataram digunakan karena Yogyakarta merupakan pusat kerajaan Mataram. Kemudian pada tanggal 27 Juli 1930 nama PSM diubah menjadi Perserikatan Sepak Bola Indonesia Mataram atau disingkat PSIM sebagai akibat tuntutan pergerakan kebangsaan untuk mencapai kemerdekaan Indonesia. PSIM sendiri saat itu sesungguhnya merupakan suatu badan perjuangan bangsa dan Negara Indonesia. (psimjogja.id/sejarah) Stadion yang digunakan sebagai laga kandang PSIM (Perserikatan Sepak bola Indonesia Mataram) adalah Stadion Mandala Krida, yang memiliki kapasitas 25.000 orang penonton. (wikipedia.org)

Pendukung PSIM:

a. Brajamusti

Dari sekian banyak pertemuan-pertemuan melibatkan laskar-laskar PSIM waktu itu maka pada tanggal 15 Februari 2003 di Yogyakarta tepatnya di Balai RK 
Mangkukusuman Markas Laskar PSIM yaitu Hooligans. H.Guntur Artamaji sebagai penggagas dikumpulnya sekelompok laskar PSIM sebelum adanya Brajamusti ( Hooligans, Mgr, Cobra Mataram, Dahkota, Baju Barat, Pathuk squad \& Cidelaras).

Arti sesungguh nya dari kata Brajamusti adalah Aji-ajian sakti dari Gatutkaca. Bima adalah salah satu dari pandawa lima, mempunyai anak Gatutkaca. Maksud dari pengambilan nama Brajamusti untuk wadah suporter PSIM adalah supaya Brajamusti menjadi senjata atau aji-ajian yang ampuh untuk PSIM untuk menghadapi lawan-lawannya dipentas sepak bola Nasional. Jadi Brajamusti selalu ada disamping PSIM dimanapun berlaga.

\section{b. The Maident}

\begin{tabular}{cc}
\multicolumn{2}{c}{ Perkembangan arah } \\
pemikiran mengehendaki pula
\end{tabular}
perubahan di dalam dunia suporter PSIM Jogjakarta. Teriakan-teriakan revolusi PSSI dimana sepakbola sudah terlalu dipandang bermuatan politik praktis baik kedaerahan dan nasional semakin sering terdengar. Hal tersebut membuat sekitar 70 laskar sejak tahun 2008 bersepakat memikirkan sebuah konsep baru. Bisa dikatakan membentuk oposisi mengusung organisasi baru. Sistem yang diharapkan mengubah kebiasaankebiasaan lama. Puncaknya pada tanggal 1 Oktober 2010 atas dasar kebersamaan yang mengutamakan prinsip atraktif, menekan total aksi anarkis di sepakbola, dan meminimalisir unsur politik maka terbentuklah The Maident.

The Maident merumuskan bahwa sudah waktunya suporter lebih berdikari. Jer basuki mawa bea, untuk mencapai sebuah cita-cita harus mau berkorban. Tidak gampang untuk menjadi independen bekalnya harus banyak. Semangat utamanya adalah "tan gumantung ing liyan" dalam berbagai hal. Maka sampai hari ini rewo-rewo menjadi salam kebersamaan yang selalu disuarakan melalui tribun utara. Semangat berdikari, berdiri di atas kaki sendiri demi PSIM Jogjakarta kembali kepada kejayaannya. Sejarah jelas mengatakan PSIM sebagai salah satu inisiator berkembangnya sepakbola di Indonesia. Persatuan Sepakraga Mataram (PSM) sebagai cikal bakal PSIM menunjukkan unsur identitas yang berbeda dibanding kelompok sepakbola di masa itu. Jadi, independensi sebenarnya sudah ada sejak embrio PSIM tersebut mulai ada. The Maident selalu memberikan totalitas dukungannya di dalam dan di luar lapangan untuk PSIM Jogja yang istimewa. Tansah nyawiji, greget, sengguh, ora mingkuh...( Chairul adi musshafak, 23 Maret 2017)

\section{Perserikatan Sepak Bola Sleman (PSS)}

Lahirnya PSS dilatarbelakangi bahwa pada waktu itu di Daerah Istimewa Yogyakarta (DIY) baru ada dua perserikatan yaitu PSIM Yogyakarta dan Persiba Bantul. (pss-sleman.co.id) Pada tahun 2004 Pemkab Sleman membangun stadion baru di wilayah Maguwoharjo. Stadion dengan kapasitas 50.000 penonton ini dibangun dengan fasilitas kelas internasional. Stadion ini memiliki tipe Stadion Sepakbola Modern dengan konsep "Mini San Siro" dengan ciri khas menara yang terletak di empat penjuru stadion dengan tangga berputarnya.

Pendukung dari PSS antara lain :

a. Slemania

Merupakan organisasi sekaligus identitas bagi pendukung kesebelasan PSS Sleman. Slemania memiliki organisasi bagian untuk suporter perempuan yang bernama Slemanona. Saat ini Slemania memiliki tidak kurang dari 18.000 anggota dan 50.000 simpatisan yang tergabung dalam 600an laskar (organisasi internal) di Daerah Istimewa Yogyakarta dan di kota-kota besar di seluruh Indonesia. Anggota Slemania sangat beranekaragam dari yang tidak mengenyam bangku sekolah sampai yang menempuh jenjang pendidikan tinggi. Begitu juga dengan latar belakang ekonomi dan profesi. 
Slemania memiliki slogan sebagai "Suporter Edan Tapi Sopan", dan pernah terpilih sebagai nominator suporter favorit dalam Sepak Bola Award-ANTV 2003 bersama The Jakmania dan Laskar Benteng Viola. The Jakmania akhirnya terpilih sebagai penerima penghargaan tersebut. Slemania kembali terpilih sebagai nominator dalam Sepak Bola Award-ANTV $2004 \quad$ bersama dengan Viking Persib dan The Macz Man. Slemania akhirnya meraih penghargaan tersebut.

Dalam kelompok suporter Slemania dikenal istilah anggota dan simpatisan Slemania. Istilah anggota dan simpatisan digunakan untuk membedakan tingkat militansi dan keaktifan seseorang di Slemania. Salah satu kebiasaan anggota Slemania adalah menempati tribun (tempat) khusus yang disebut Curva Nord, dan biasa bernyanyi dan beratraksi saat pertandingan. (wikipedia.org)

b. BCS ( Brigata Curva Sud )

BCS atau singkatan dari Brigata Curva Sud sudah ada saat tahun 2003 sejak suporter PSS baru ada satu yaitu Slemania. Kemudian diorganisasi tersebut juga lahir bibit-bibit atau kelompokkelompok yang mempunyai gaya dukung tersendiri makanya saat itu ada yang namanya arus bawah ultras PSS kemudian, dari ultras PSS ditahun-tahun 2004 atau 2005 mereka sudah mempunyai cara pandang sendiri dan mereka terapkan di Slemania. Akhirnya, mereka menginisiatif adanya BCS ( Brigata Curva Sud ) tersebut. Jika disimpulkan, BCS lahir karena ketidak sukaan dan ketidak puasan akan organisasi sebelumnya jadi, minoritas akhirnya mereka berdiri sendiri. Didalam BCS ada sub-sub atau komunitas yang sudah berjumlah 150 komunitas. Komunitas Titik Hitam dan Ladies Curva Sud (sebutan untuk suporter wanita) adalah sebagian komunitas tersebut. (Vikar, 2018)

Sepakbola adalah hasil kreativitas manusia, dari dan ketika ia diciptakan sampai bagaimana sepakbola tersebut dimainkan. Dalam skala industri, sepakbola adalah pekerjaan yang berorientasi pada keuntungan finansial (pemain,manajemen), sekaligus menjadi kebutuhan hiburan bagi para pendukungnya (suporter). Bagi sebagian yang lain, sepakbola tidak berhenti pada kata "hiburan" semata, namun ada semangat, kebanggaan dan cinta yang terpatri di sana. Dari dua ketergantungan tersebut, sepakbola nyatanya adalah sebuah permainan yang tidak bisa dimainkan dengan bermain-main, karena ada tanggung jawab dan target pencapaian. Rentetan gesekan dengan kelompok lain ataupun malah dengan teman sendiri, baik di dalam maupun di luar stadion yang akhir-akhir ini sering terjadi, sepakbola gajah, dan deretan peristiwa yang terjadi karena ulah suporter seolah menegaskan "Semakin tinggi pohon, maka akan semakin kencang angin menerpanya". Rasanya ini menjadi sangat penting, sebagai manusia yang terus bergerak dalam gelombang dukungan yang tak terbatas. Untuk berjumpa, duduk bersama, laku wening, mendengarkan, menanyakan, merangkul serta semoga bisa mengkoreksi yang sudah kita lalui. Di depan jalan terpapang panjang, sudah semestinya sebagai permulaan kita saling menegasakan rasa ini kembali. Sembari mengkaji makna manusia yang seutuhnya di hadapan pribadi dan orang lain.

Karakter suporter berdasarkan pendidikan dan umu

\begin{tabular}{|c|c|}
\hline SD - SMP & $7-15$ tahun \\
\hline SMA / SMK & $16-18$ tahun \\
\hline Kuliah - Bekerja & $19-50$ \\
& tahun \\
\hline
\end{tabular}
Kelamin

Karakter suporter berdasarkan Jenis

\begin{tabular}{|c|c|}
\hline Laki-laki & $70 \%$ \\
\hline Perempuan & $30 \%$ \\
\hline
\end{tabular}

\section{Solidaritas Anarkisme Suporter Sepak Bola PSIM dan PSS Serta Proses Pemberdayaannya.}

Durkheim membagi dua tipe solidaritas yaitu solidaritas mekanis dan solidaritas organis. Solidaritas mekanis berpijak pada tingkatan homogenitas tinggi 
dalam kepercayaan, sentimen, pekerjaan, dan lain-lain. Masyarakat yang ditandai oleh solidaritas mekanis menjadi satu dan padu karena orang adalah generalis. Hubungan masyarakat terjadi karena mereka terlibat aktifitas yang sama dan memiliki tanggung jawab yang sama. Solidaritas organis terjadi karena pembagian kerja yang semakin banyak, penambahan jumlah pembagian kerja akan mengakibatkan ketergantungan. Masyarakat yang ditandai oleh solidaritas organis bertahan bersama justru dengan perbedaan yang ada di dalamnya, karena adanya rasa ketergantungan antara satu dengan yang lain. Dengan fakta bahwa semua orang memiliki pekerjaan dan tanggung jawab yang berbeda-beda.

Indikator pokok yang penting solidaritas yaitu :

a. Ruang lingkup dan kerasnya hubungan yang bersifat represif atau menekan.

b. Hukum itu didefinisikan bahwa penyimpangan dianggap sesuatu yang jahat dan mengancam kesadaran kolektif.

c. Memiliki aturan sosial atau kesepakatan bersama (Razak, perkembangan teori sosial).

Mikhail Bakunin (1814-1876) menjelaskan mengenai anarkisme yang disamakan dengan tindak kekerasan dan pembunuhan. Pembunuhan kepala negara, serangan bom atas gedung-gedung milik negara, dan perbuatan teroris lain dibenarkan oleh anarkisme sebagai cara untuk menggerakkan massa untuk memberontak. (Suseno, PEMIKIRAN KARL MARX) Mengikuti pendapat D. Black (1977:123), anarkisme adalah sebuah kehidupan masyarakat tanpa undang-undang dan tanpa pemerintahan yang mengawasi masyarakat.

Terdapat faktor-faktor solidaritas anaskisme sebagai berikut :

a. Solidaritas

Hubungan individu dan masyarakat sarana yang digunakan individu untuk dapat bekerja sama memenuhi kepentingan bersama dalam sebuah lingkungan yang mendukung dan memelihara baik kebebasan maupun kesetaraan. Oleh karena itu solidaritas penting bagi kaum anarkis karenma merupakan sarana bagi terciptanya kebebasan dan bertahan terhadap kekuasaan. b. Perkumpulan

Harus didasarkan pada kesetaraan dan individualitas untuk benar-benar memuaskan mereka yang bergabung di dalamnya (Anarkis.org, 2013)

c. Kekuatan Gerakan Massa

Massa merupakan sumber kekuatan revolusi bahwa revolusi berlangsung berdasarkan suatu bentuk tindakan spontan dari rakyat. "Sebuah revolusi sosial ... tidak berlangsung atas perintah seorang tokoh dengan teori yang sudah jadi, atau sabda seorang nabi. Revolusi organik yang sesungguhnya adalah buah dari kehidupan universal, dan meskipun revolusi ini punya para pewarta dan pelakunya sendiri, ia bukanlah kerja dari satu orang saja." PierreJoseph Proudhon (Hutagalang, 2007)

Suporter sepak bola adalah kerumunan yang anggotanya berdomisili relatif berada dalam satu wilayah serta memiliki kesamaan minat untuk mendukung tim yang bertanding dan merasa memiliki keterikatan dengan klub tersebut. Setiap pertandingan sepak bola terdapat para pendukung atau suporter yang menanti akan pertandingan tim kesebelasan mereka terutama para suporter di Yogyakarta. Suporter sepak bola merupakan orang yang datang menonton pertandingan ke lapangan dan membeli tiket masuk. Ada juga suporter sepak bola yang menonton pertandingan tidak datang ke stadion tetapi memilih menonton melalui televisi atau media elektronik yang lain. Sehingga mereka tetap dapat mendukung tim sepak bola andalan masing-masing. Informan yang mengatakan bahwa tidak ada persyaratan untuk menjadi bagian suporter sepak bola.

Al Basit informan yang berasal dari Riau mengatakan bahwa

"tidak ada persyaratan untuk menjadi bagian suporter"

Dari pernyataan tersebut berarti untuk menjadi suporter sepak bola tidak ada ikatan atau paksaan sama sekali. Suporter sepak bola dibuka untuk umum dari berbagai macam usia dan jenis kelamin. Mereka yang berumur tua, muda, berjenis 
kelamin perempuan dan lelaki pun bisa menjadi bagian dari suporter sepak bola Tidak ada batasan wilayah untuk mendukung tim sepak bola. Suporter sepak bola bisa berasal dari penjuru Indonesia untuk menjadi pendukung tim sepak bola yang mereka anggap patut untuk didukung. Bukan berarti jika tim sepak bola di daerah asal mereka jelek atau tidak baik. Dari asal daerah dia yang jauh seperti itu, dia memilih untuk mendukung PSS Sleman karena :

"awalnya saya suka PSS karena berawal dari suporter itu sendiri yaitu BCS itu sendiri. Banyak informasi PSS itu punya suporter yang loyal, kreatif, dari situlah awalnya saya tertarik dan bergabung."

Informasi mengenai BCS sebagai pilihan untuk menjadi suporter dia dapatkan dengan banyak informasi dari media dan teman-temannya yang berada di sekitarnya, bahwa tim yang dia dukung itu mempunyai suporter yang loyal dan kreatif. Sehingga dia menjadi tertarik dan ikut bergabung untuk mendukung tim tersebut. Tidak hanya informan dari luar daerah yang mengatakan demikian. Para suporter yang lain pun juga membenarkannya. Hanya sedikit yang mengatakan bahwa jika ingin menjadi bagian suporter ada persyaratan tapi hanya untuk bergabung dengan komunitaskomunitasnya saja. Berarti terdapat 2 jenis suporter yaitu suporter sendiri yang mendukung sendiri tanpa ikut komunitas atau grup-grupan dan suporter yang ada di dalam komunitas maupun grup.

Seperti yang dikatakan oleh Luthfi Fadila N.H mengatakan :

"itu tergantung mau ikut grup-grupan suporter atau suporter sendiri.”

Ketika sudah masuk ke dalam sebuah komunitas para suporter menjadi lebih sering menonton dan meluangkan waktu untuk komunitas itu. Meluangkan waktu untuk sering berkumpul atau ikut berpartisipasi dalam kegiatan yang dilakukan oleh komunitas tersebut. Dengan berbagai macam nama komunitas tetap mendukung tim yang sama hanya berbeda nama komunitasnya saja.

Dari saudara Wisnu menambahkan bahwa : "persyaratan yang diberikan tidak ada. Cuman kalau suka tinggal ikut saja. Kemudian mengikuti perkembangan tim.
Kalau ada waktu luang, ada dana dan tidak ada kerjaan mending nonton saja."

Berarti memang tidak ada persyaratan untuk menjadi suporter sepak bola. Untuk menjadi suporter itu gampang karena ketika memang benar-benar suka tinggal datang menonton ke lapangan selama ada ketersediaan waktu, uang untuk membeli tiket dan tidak ada kerjaan yang mengganggu lebih baik datang menonton. Jika tidak bisa menonton ketika tim yang didukung sedang main, bisa mengikuti perkembangannya lewat media sosial. Sehingga tidak ketinggalan untuk informasi perkembangan tim sepak bola.

Ketika bisa datang untuk menonton pertandingan, disetiap match atau pertandingan mereka suporter yang mengikuti grup atau komunitas berbondongbondong datang menonton ke stadion dimana kesebelasan yang mereka dukung itu bertanding. Mereka datang dari berbagai tempat yang jaraknya jauh maupun yang dekat hanya untuk datang menonton sepak bola kebanggaannya. Jarak yang begitu jauh merupakan hal yang tidak mempengaruhi keinginan mereka untuk datang menonton pertandingan dimanapun berada sehingga tidak menjadi masalah. Mereka rela menghabiskan waktu luang untuk bepergian jauh agar tetap dapat menonton sepak bola kebanggaannya saat bertanding.

Seperti yang dikatakan seorang informan berumur 24 tahun

"ga ada masalah dengan jarak. Kalau udah dari hati kemana pun berangkat."

Mega Purwaning T. juga menambahkan bahwa:

"jarak tempat tinggal tidak mempengaruhi untuk datang menonton pertandingan."

Untuk sebagian besar suporter sepak bola jarak memang tidak mempengaruhi mereka ketika memang benar-benar sudah cinta terhadap tim kebanggaannya. Jadi, dimana pun tempatnya akan tetap datangLarangan dari orang tua juga mempengaruhi mereka yang tidak dapat menonton pertandingan karena jarak tempat yang jauh. untuk menonton pertandingan sepak bola timnya tersebut. Beberapa informan yang mengatakan bahwa tidak bisa 
menonton dengan jarak yang begitu jauh. Bukan berarti mereka tidak mendukung dengan hati tetapi karena kendala dari orang tua masing-masing suporter.

Seperti yang dikatakan oleh saudara Azhar Wicaksono bahwa :

"jarak tempat tinggal sangat
mempengaruhi untuk datang menonton
pertandingan karena kalau jauh sering
dilarang oleh orang tua."

Graham (1976) juga mengartikan suporter sebagai individu maupun kelompok yang hadir pada suatu pertandingan olahraga dengan tujuan menunjukkan dukungannya kepada salah satu tim yang bertanding dan merasa memiliki keterikatan dengan klub tersebut. Dalam konteks ini olahraga yang mereka dukung adalah sepak bola. Jadi suporter ini mendukung tim sepak bola yang mereka pilih. Walaupun berbeda tim sepak bolanya mereka tetap menjadi bagian dari tim tersebut dan tetap mendukungnya. Jarak yang begitu jauh juga tidak menjadi masalah para suporter sepak bola ketika mereka ingin mendukung tim sepak bola yang mereka dukung. Untuk beberapa suporter yang ingin menoton pertandingan dengan jarak yang jauh, kendala mereka adalah atas ijin orang tua mereka masing-masing yang susah. Kekawatiran orang tua juga beralasan karena mereka tidak ingin terjadi hal-hal yang tidak diinginkan ketika anak mereka berpergian jauh hanya untuk menonton pertandingan sepak bola.

\section{Solidaritas Suporter Sepak Bola PSIM dan PSS.}

Solidaritas anarkisme suporter sepak

bola PSIM dan PSS tidak terlepas dari indikator pokok yang penting dari solidaritas itu sendiri. Solidaritas menunjuk pada satu keadaan hubungan antar individu dan/atau kelompok yang didasarkan pada perasaan moral dan kepercayaan yang dianut bersama yang diperkuat oleh pengalaman emosional bersama. Ikatan ini lebih mendasar daripada hubungan kontraktual yang dibuat atas persetujuan rasional (Paul, teori sosiologi klasik dan modern). Dari solidaritas tersebut muncul perasaan moral dan kepercayaan dari para suporter bola PSIM dan suporter bola PSS dengan sikap menjaga kebersamaan mereka antar sesama suporter. Seorang informan suporter PSIM berumur 23 tahun yang tidak mau disebut namanya mengatakan bahwa :

"sikap menjaga kebersamaan antar sesama suporter pasti ada karena kita sama-sama suporter PSIM sudah seperti keluarga sendiri pasti ditolong dengan tetap menjaga silahturahmi dan selalu berkomunikasi"

Dengan demikian dapat diartikan bahwa sikap menjaga kebersamaan antar sesama suporter pasti ada. Banyak cara yang dapat dilakukan untuk menjaga kebersamaan. Salah satunya dengan berkomunikasi. Silahturahmi dan komunikasi itu sangatlah penting agar tetap dapat terkontrol dengan baik dan tetap dapat dilakukan dimana saja. Solidaritas adalah rasa kebersamaan, rasa ketergantungan yang sama atau bisa diartikan perasaan atau ungkapan dalam sebuah kelompok yang dibentuk oleh kepentingan bersama dan tanggung jawab yang berbeda-beda. Sikap menjaga kebersamaan antar sesama suporter tidak hanya dilakukan oleh satu atau dua orang saja.

Sikap menjaga solidaritas oleh suporter sepak bola juga diperlihatkan disaat sedang terjadinya kericuhan.

Azhar Wicaksono sebagi suporter PSIM juga mengatakan bahwa :

"menjaga kebersamaan antar sesama suporter itu ada dengan saling mengingatkan antar suporter ketika melakukan tindakan kekerasan yang kurang perlu dilakukan sehingga merugikan tim itu sendiri."

Dapat diartikan bahwa tidak ingin ada kekerasan yang terjadi dan mengupayakan untuk saling mengingatkan antar sesama suporter agar tidak terjadi halhal atau tindakan yang kurang perlu dilakukan karena dapat merugikan tim sepak bola yang sedang bertanding. Sikap menjaga kebersamaan antar sesama suporter itu harus ada supaya tidak terjadi hal-hal yang tidak diinginkan. Sikap menjaga kebersamaan juga tidak memandang tua atau pun muda yang terpenting adalah sikap untuk menjaga kebersamaan. Tidak hanya suporter PSIM 
saja tetapi suporter PSS juga melakukan tindakan tersebut.

Saudara Praditya Bayu A. Sebagai suporter

PSS menambahkan bahwa :

"ya mbak, malah kita sesama suporter meskipun kita belum kenalpun kekeluargaannya lebih erat dari pada temen kita sendiri sebenarnya. Sebagai contoh waktu itu, belum lama ini waktu malam minggu saya nonton PSS di Maguwoharjo motor saya waktu pulang macet di ring road. Nah, ada salah satu suporter mas-mas dan mbak-mbak berbonceng berdua berhenti disamping saya nanyain motornya kenapa. Macet po? nah seperti itulah yang saya suka dari suporter. Kekeluargaanya erat."

Yeni Ayu Pradiva sebagai suporter

perempuan mengatakan bahwa :

"pasti selalu menjaga kebersamaan.

Terutama mengutamakan perempuan.

Biasanya yang cowok-cowok itu melindungi.

Mereka melindungi perempuana juga supaya tidak terkena imbas dari keributan atau kericuhan yang terjadi saat pertandingan berlangsung maupun diluar pertandingan agar para perempuannya tetap terjaga dengan aman. Sikap menjaga kebersamaan itu ditunjukan oleh para suporter lelakinya.

Teman adalah segalanya untuk sebagian besar suporter sepak bola dimanapun berada. Anggapan bahwa menyakiti suporter lain demi melindungi teman sesama suporter yang sama itu tidak salah.

Seorang informan berumur 24 tahun mengatakan bahwa:

"gak ada salahnya menyakiti suporter lain demi melindungi teman sesama suporter yang sama."

Melindungi teman sesama suporter itu lebih penting dari pada hanya diam saja melihat temannya disakiti oleh suporter lain. Sehingga munculah solidaritas untuk melindungi teman sesama suporter dengan melakukan tindakan yang dapat menyakiti suporter lain. Seperti jika dipukul akan dibalas memukul juga. Dari situ dapat memunculkan tindakan yang dapat ditiru oleh suporter lain bila temannya disakiti oleh suporter lain.
Sedangkan Wisnu seorang informan mengatakan bahwa :

"tergantung suasana. Kalau pas kita bisa melindungi diri dengan cara apa. Cuma nanti pas bisa diselesaikan dengan omongan, ada juga yang langsung diserang gak tanya-tanya."

Menyelesaikan masalah itu tidak harus menyakiti suporter lain karena bisa diselesaikan dengan musyawarah atau saling ngobrol satu sama lain agar tidak terjadi kericuhan yang tidak diinginkan. Dengan tidak adanya musyawarah pasti akan terjadi hal-hal yang tidak diinginkan. Keributan atau kericuhan akan terjadi begitu saja tanpa tau penyebabnya dan akan seperti itu terus menerus. Maka dari itu sangatlah penting untuk diselesaikan secara baik-baik.

Ketika menjaga kebersamaan dan menyakiti suporter lain demi melindungi teman sesama suporter yang sama pasti ada resiko yang didapat. Apapun bentuk resiko iu pasti merugikan diri sendiri dan orang lain. Tindakan menjaga tingkah laku dan tetap berkomunikasi untuk tetap menjaga kebersamaan menjadi salah satu yang harus dilakukan untuk semua suporter agar tetap terjaga dengan baik. Akibat atau resiko tidak hanya diterima oleh diri sendiri tapi semua yang ada disekelilingnya.

Irfan Kafifi juga mengatakan bahwa :

"resiko yang didapat ketika melindungi teman itu pasti ada tapi ya gimana kalau teman kita tersakiti kita diam saja. Kita juga harus melindungi teman karena teman adalah segalanya."

Resiko yang didapat saat melindungi teman pasti ada. Karena telah melakukan tindakan melindugi. Apapun alasan untuk melindungi teman tetap saja ada baik buruknya yang akan muncul diawal atau diakhir. Jadi, harus menanggung apapun resikonya. Karena sebuah tindakan itu pasti akan ada dampak yang diberikan.

Terdapat tiga indikator pokok yang penting dalam solidaritas seperti yang dikatakan Razak. Pertama, adalah ruang lingkup dan kerasnya hubungan yang bersifat represif atau menekan sudah terjadi ketika mendapat ancaman yang diberikan ketika melindungi teman sesama suporter. Kedua, yaitu hukuman yang didefinisikan bahwa penyimpangan dianggap sesuatu 
yang jahat dan mengancam kesadaran kolektif itu tidak diperdulikan oleh beberapa suporter. Karena seperti yang mereka katakan bahwa setiap tindakan ada resikonya dan ditanggung sendiri. Ketiga, yaitu memiliki aturan sosial atau kesepakatan bersama. Dalam hal ini tidak terjadi karena beberapa suporter lebih mementingkan temannya sendiri karena teman adalah segalanya. Dari ketiga indikator seperti yang telah dipaparkan diatas, indikator pertama dan kedua menggambarkan solidaritas suporter sepak bola dalam melindungi teman sesama suporter. Indikator ketiga tidak menggambarkan mereka akan melakukan tindakan kekerasan dan tidak memerlukan kesepakatan bersama dalam menyelesaikan masalah yang muncul.

\section{Anarkisme Suporter Sepak Bola PSIM dan PSS.}

Anarkisme disamakan dengan tindak kekerasan dan pembunuhan. Anarkisme adalah tindak kekerasan dan pembunuhan sebagai cara untuk menggerakkan massa untuk memberontak atau melakukan penyerangan. Perilaku yang tidak terpuji yang ditunjukan oleh sebagian orang atau kelompok untuk melakukan sebuah tindakan yang disengaja maupun tidak disengaja sehingga merugikan diri sendiri dan kelompok. Ketika mereka diserang oleh oknum-oknum yang mengatas namakan suporter lain otomatis atau secara tidak sengaja pasti akan ada kejadian yang tidak diinginkan. Keributan atau kericuhan akan terjadi secara langsung didalam maupun diluar stadion.

Seperti yang dikatak suporter yang berumur 24 tahun bahwa :

"ketika kami pulang dan pergi dari menonton pertandingan sepak bola kemudian diserang secara tiba-tiba diluar stadion secara bersama-sama atau ramairamai oleh oknum-oknum suporter lain. Kami akan otomatis melawan secara bersama-sama juga untuk membela diri."

Suporter yang berjumlah banyak tidak akan diam saja jika mereka diserang oleh oknum-oknum yang mengganggu mereka atau membuat keributan dijalanan waktu pulang atau pergi untuk menonton pertandingan sepak bola. Mereka berupaya untuk melawan karena mereka otomatis atau secara langsung terlibat dalam hal tersebut. Kemudian akan terjadi tindakan kekerasan walaupun tindakan tersebut tidak direncanakan karena terjadi secara tiba-tiba, tidak ada suporter yang mengetahui jika akan terjadi penyerangan oleh oknumoknum tersebut.

Kelompok suporter sepak bola merusak fasilitas yang berada di stadion sehingga membuat keributan dan merugikan berbagai pihak terutama para pemainnya. Pertandingan yang berlangsung sudah tidak dapat dinikmati lagi kerena ulah para suporter tersebut. Secara langsung membuat kericuhan terjadi di stadion tersebut.

Pemain sepak bola pun juga menyayangkan apabila ada kericuhan yang terjadi dilapangan saat mereka bertanding. Sebagian pemain sepak bola juga khawatir akan kejadian-kejadian didalam lapangan maupun diluar lapangan. Para pemain sepak bola juga menginginkan supaya saat pertandingan sepak bola berlangsung tidak terjadi kericuhan atau kejadian-kejadian yang tidak perlu dilakukan oleh para suporter sepak bola.

Wahyu Sukarta sebagai pemain sepak bola mengutarakan bahwa :

"kadang liat mereka ricuh saat pertandingan itu membuat pemain tidak fokus, menyayangkan kenapa kejadian itu terjadi. Sangat merugikan tim juga disisi pemain jadi tidak fokus juga nanti akibatnya semisal tim atau suporter mendapat denda dari federasi kalau rusuh terus jatuh korban juga nanti yang repot dari suporter sendiri kasian kalau ada korban yang luka maupun sampai meninggal dunia. Kami sebagai pemain menyanyangkan, kalau bisa yang di stadion jangan sampai rusuh.” ( 4 April 2018 )

Saat kumpulan suporter melakukan tindakan kericuhan, para pemain sangat kawatir dan mengganggu pertandingan yang sedang berlangsung. Yang dirugikan adalah para pemain dan juga suporter lain yang tidak melakukan tindakan kericuhan atau kekerasaan saat di luar atau pun di dalam stadion. Denda seperti uang yang nominalnya tidak sedikit, tim sepak bola 
saat bertanding tanpa suporter dan tim tidak boleh main di stadion sendiri menjadi bagian dari akibat yang dilakukan oleh suporter. Para pemain menyayangkan hal tersebut. Akibat yang dibuat saat kericuhan memberikan dampak yang tidak baik untuk sebagian suporter juga. Sebenarnya para pemain juga sangat kecewa kepada sebagian suporter yang melakukan atau korban dari tindakan kekerasan dan kericuhan yang terjadi di dalam stadion atau pun di luar stadion. Harapan mereka yang begitu besar kepada para suporter terkadang tidak dihiraukan oleh suporter itu sendiri.

Supriyadi sebagai pemain juga menambahkan bahwa :

"kericuhan yang terjadi karena suporter dapat memecahkan konsentrasi. Kita langsung melihat yang ricuh bagaimana korbannya terus pasti pertandingan diperhentikan."

Kericuhan yang dilakukan oleh para kelompok suporter sangat mengganggu dan dapat memecahkan konsentrasi para pemainnya. Para pemain juga kawatir akan korban-korban yang berjatuhan ketika kericuhan terjadi dan saat itu juga pertandingan akan diperhentikan sehingga membuat para pemain tidak bisa melanjutkan pertandingan karena kericuhan yang terjadi. Kericuhan yang terjadi membuat keselamatan para suporter didalam stadion saat pertandingan berlangsung juga membuat cemas para pemainnya karena pasti ada korban. Resikonya adalah korban menjadi luka-luka dan sampai menelan jiwa. Padahal yang diinginkan para pemain adalah suporter yang tidak membuat kericuhan sehingga mereka dapat bermain secara fokus dan dapat memberikan hasil yang memuaskan untuk para suporter.

Solidaritas anarkisme yang muncul dari suporter sepak bola adalah cara mereka untuk mendukung tim kesebelasan sepak bola. Solidaritas yang begitu kuat mereka tunjukan hanya untuk melindungi teman sesama suporter walaupun mereka mengetahui dampak atau resiko yang akan didapat ketika melindungi teman sesama suporter. Untuk sebagian suporter, melakukan tindakan anarkisme sudah mulai tidak dilakukan karena mereka lebih suka menjadi suporter yang biasa saja walaupun ada dua tipe suporter yang fanatik dan suporter yang biasa saja. Tidak menutup kemungkinan bahwa suporter sepak bola untuk tahun-tahun kedepan sudah mulai berkurang dalam hal tindakan anarkisme.

Didalam komunitas atau kelompok pada suporter sepak bola tentunya ada faktor-faktor yang membangun agar kekompakan suporter tetap terjaga dan tetap menjaga nama baik suporter dan tim. Faktor-faktor solidaritas anarkisme adalah anti-dominasi, anti-pemaksaan serta kesetiakawanan antar individu dan kelompok untuk melakukan tindakan kekerasan. Anti-dominasi yang diartikan sebagai menolak atau tidak setuju dengan adanya kegiatan bersama-sama antar suporter lain. Anti-pemaksaaan merupakan tindakan yang menolak atau tidak setuju dengan adanya kegiatan bersama-sama antar suporter secara paksa. Kemudian kesetiakawanan terhadap suporter lain.

Luthfi Fadila N.H mengatakan :

"saya setuju bila ada kegiatan bersamasama antar suporter lain. Karena dapat mempererat tali persaudaraan antar suporter lain."

Berarti dalam kegiatan bersamasama antar suporter sangat mempengaruhi hubungan antar suporter lain yang memberikan efek baik dalam tali persaudaraan antar suporter lain. Dengan begitu para suporter dapat tetap menjaga kebersamaannya dalam melakukan tindakan positif. Mereka setuju bila ada kegiatan bersama-sama antar suporter lain. Karena dengan begitu akan terciptanya suasana kekeluargaan didalam maupun diluar kegiatan dan mengurangi tindakan-tindakan yang tidak diperlukan. Saat bertemu di jalan atau di tempat nongkrong dapat memberikan suasana yang baik tanpa harus berseteru dengan suporter lain.

Raden Zidai P. mengatakan bahwa : "ya saya setuju. Karena kegiatan itu menjadi lebih dekat atau akrab dengan suporter dari komunitas lain."

Dengan demikian, sudah pasti bahwa harapan untuk kegiatan bersama-sama secara positif dengan suporter lain membuat para suporter akan lebih akrab dengan 
suporter lain. Sehingga dapat menciptakan untuk kedepannya hal-hal yang semakin baik dari suporter lain atau komunitaskomunitas lainnya dan tidak menginginkan tindakan yang memunculkan kekerasan dalam perbedaaan dengan suporter lainnya. bahwa:

Irfan Kafifi juga menambahkan

"setuju karena dengan kegiatan ini kita bisa mempererat persaudaraan kita walaupun kita beda visi misi kita tetap satu Yogyakarta."

Diperlukan ikatan erat dalam satu wilayah. Karena dalam satu wilayah terdapat berbagai macam komunitas yang ada didalamnnya. Isi dari berbagai macam visi dan misi disetiap komunitas yang ada pasti akan berbeda-beda. Tergantung dengan cara mereka menyikapinya. Para suporter berharap akan kemajuan suporter lain untuk menjadi satu dalam satu wilayah juga. Tidak saling menjatuhkan hanya karena berbeda tim yang didukung. Karena tim kesebelasan mereka berasal dari wilayah yang sama yaitu Yogyakarta. Hanya berbeda kabupatennya saja. Walaupun berbeda misi dan visi tetap menjadi bagian dari satu wilayah yaitu Yogyakarta. Padahal dilaur sana banyak tim yang berbeda-beda tetapi orang-orangnya atau para suporter yang berbeda tetap bisa berteman baik. Maksudnya adalah mereka berteman baik padahal mereka berbeda dukungan untuk mendukung tim tanpa memandang tim mana yang mereka dukung. Mereka masih bisa melakukan hal positif bersama-sama tanpa ada kekerasan atau kerusuhan.

Menurut Okta Krisna I. bahwa :

"ada suporter sepak bola yang lain itu lebih baik"

Meydiana T.F seorang informan wanita mengatakan bahwa :

"engga juga. Suporter sepak bola lain enggak lebih baik. Sebenarnya semua suporter itu sama saja, tergantung dari orang-orangnya mau jadi keliatan lebih baik, mau jadi suporter yang baik atau enggak tergantung sama orang-orangnya."

Suporter mempunyai cara yang bedabeda untuk meluapkan kebanggaannya kepada tim sepak bola mereka. Baik buruknya seorang suporter tergantung oleh diri mereka sendiri. Ketika mereka melakukan tindakan anarkisme berarti mereka menjadi bagian suporter yang anarkis. Sedangkan suporter yang memilih untuk biasa saja pasti tidak ingin ikut dalam tindakan anarkisme dan memilih menonton secara tenang. Untuk menilai baik buruknya suporter tetap kembali ke dalam diri masingmasing tiap suporter itu.

Seperti yang dikatakan Yeni A.P sebagi suporter PSS bahwa :

"karena suporter PSS mempunyai solidaritas yang kuat dan kekeluargaan."

Berarti dia menganggap bahwa suporter PSS itu lebih baik dibanding yang lain di karenakan mempunyai solidaritas yang kuat dan kekeluargaannya yang erat. Solidaritas yang kuat dan kekeluargaan yang erat ditunjukan oleh suporter BCS (Brigata Curva Sud) untuk melindungi suporter LCS (Ladies Curva Sud) mereka. Ada banyak alasan. Karena ada pengaruh wilayah tempat tinggal mereka, ajakan saudara, teman maupun keluarga jadi mereka mengikuti sampai sekarang.

Seorang suporter PSIM berumur 24 tahun yang tidak mau disebut namanya juga mengatakan bahwa :

"karena suporter PSIM tidak mencari

muka di sosial media."

Ada suporter sepak bola yang hanya mementingkan sosial media dalam hal apa saja. Sehingga memunculkan anggapan bahwa ada sebagian suporter yang lebih mementingkan ke sosial medianya. Dan masih banyak alasan-alasan yang diberikan ketika mereka menolak bahwa tidak ada yang lebih baik. Salah satunya anggapan bahwa suporter mereka sendiri itu lebih baik karena tidak ikut berperan dalam sosial media.

Terdapat faktor-faktor solidaritas anarkisme sebagai berikut, Pertama, adanya spildaritas.Hubungan individu dan masyarakat sarana yang digunakan individu untuk dapat bekerja sama memenuhi kepentingan bersama dalam sebuah lingkungan yang mendukung dan memelihara baik kebebasan maupun kesetaraan. Oleh karena itu solidaritas penting bagi kaum anarkis karena merupakan sarana bagi terciptanya kebebasan dan bertahan terhadap 
kekuasaan.Dalam hal ini tindakan yang terjadi adalah saat mereka melindungi teman sesama suporter sepak bola dan mereka akhirnya melakukan tindakan kekerasan atau tindakan anarkis terhadap suporter lain. Berarti tingkat solidaritas mereka cukup tinggi dalam membela teman sesama suporter tetapi tidak menutup kemungkinan dengan membela teman sesama suporter membuat mereka dirugikan. Kedua, perkumpulan. Harus didasarkan pada kesetaraan dan individualitas untuk benarbenar memuaskan mereka yang bergabung di dalamnya (Anarkis.org, 2013) Dalam suporter sepak bola mereka memberikan cara yang terbaik untuk mendukung tim kesebelasan saat bertanding agar tim yang mereka dukung selalu mendapat dukungan yang terbaik dari para suporter sepak bola dengan menyanyikan yel-yel dan datang menonton membeli tiket. Dengan kesadaran dari diri mereka masing-masing secara individu yang datang langsung dan membeli tiket, mereka sudah menunjukan kepedulian mereka untuk menjadi suporter yang loyal. Ketiga, kekuatan gerakan masa. Massa merupakan sumber kekuatan revolusi bahwa revolusi berlangsung berdasarkan suatu bentuk tindakan spontan dari rakyat. "Sebuah revolusi sosial ... tidak berlangsung atas perintah seorang tokoh dengan teori yang sudah jadi, atau sabda seorang nabi. Revolusi organik yang sesungguhnya adalah buah dari kehidupan universal, dan meskipun revolusi ini punya para pewarta dan pelakunya sendiri, ia bukanlah kerja dari satu orang saja." PierreJoseph Proudhon (Hutagalang, 2007)

Perilaku anarkisme sering ditemukan disebagian besar suporter sepak bola.

Seperti yang telah Wahyudi

Sulaiman katakan bahwa

"selama menjadi suporter belum pernah melakukan tindakan kekerasan karena saya itu mendukung tidak harus rasis terhadap suporter lain. Kita harus menjadi suporter yang biasa."

Dapat dikatakan bahwa ada 2 tipe suporter yang fanatik dan suporter yang biasa saja. Memang tidak harus rasis untuk menjadi seorang suporter agar tetap menjaga kebersamaan di stadion ataupun dimana pun.
WS sudah menjadi suporter sepak bola sejak dia sekolah dasar (SD) hingga kini dia lulus sekolah menengah atas (SMA). Selama itu dia merupakan suporter yang tidak fanatik.

Tegar Alda N. Juga mengatakan bahwa :

"tidak pernah, karena saya bukan suporter anarkis."

Untuk suporter muda-muda jaman sekarang lebih memilih menjadi suporter yang biasa saja agar tidak menjadi suporter yang rasis dan merugikan tim sepak bola yang mereka dukung. Sehingga mereka tidak pernah melakukan tindakan kekerasan didalam maupun diluar lapangan.

Untuk sekarang ini para suporter sudah mulai memberikan tindakan yang tidak anarkis terbukti dari diri mereka masing-masing. Terutana suporter perempuannya tidak ada yang melakukan tindakan kekerasan ataupun kericuhan dalam konteks ini. Karena saat melakukan tindakan kekerasan dapat merugikan diri sendiri dan akan ada sanksi dari pihak DPP ( Dewan Perwakilan Pusat ) berupa denda, pertandingan tanpa penonton, dan laga usiran (tim tidak boleh bermain di stadionnya sendiri) seperti yang sudah dipaparkan diatas. Manfaatnya pun tidak ada saat melakukan tindakan kekerasan. Maka dari itu beberapa suporter memilih tidak melakukan tindakan kekerasan. Upaya untuk membuat pertandingan berlangsung tanpa adanya kericuhan juga sudah dilakukan hanya saja mereka tetap kewalahan dengan oknum-oknum yang mengatas namakan suporter.

Dari paparan diatas dapat disimpulkan bahwa faktor-faktor solidaritas anarkisme itu memang ada. Salah satunya adalah melakukan tindakan positif untuk masyarakat walaupun mereka semua mempunyai perbedaan dalam visi dan misi, dan berbeda-beda komunitasnya mereka tetap dapat bersatu. Ketika mereka menolak untuk melakukan kegiatan positif bersama alasannya karena kegiatan itu dilakukan bersama suporter rival mereka tetapi mereka semua setuju dengan kegiatan positif. Anggapan suporter mana yang lebih baik atau tidak lebih baik ketika melakukan kegiatan positif tetap saja itu tidak menjadi 
masalah tergantung diri mereka masingmasing.

\section{Pemberdayaan}

Pemberdayaan bertujuan meningkatkan keberdayaan dari mereka yang dirugikan (the disadvantaged). Jim Ife membagi pandangan pemberdayaan ke dalam beberapa kelompok:

a. Perspektif Struktural

Dari perspektif struktural ini, pemberdayaan adalah agenda yang jauh lebih menantang, karena hal hanya dapat dicapai secara efektif jika bentuk-bentuk struktur yang merugikan ini ditantang dan diatasi. Oleh karena itu, pemberdayaan selalu merupakan bagian dari program perubahan sosial yang lebih luas dengan pandangan untuk melucuti struktur-struktur opresif yang dominan.

Dalam konteks pemberdayaan di dalam suporter sepak bola ini tidak ditemukan hal yang dapat dicapai secara efektif untuk perubahan sosial yang lebih luas karena dalam pemberdayaan ini sifat dari pemberdayaannya hanya untuk kalangan sendiri. Hasil yang didapat juga hanya untuk kalangan sendiri misalnya membantu keuangan tim sepak bola.

b. Perspektif Pluralis

Dari suatu perspektif pluralis, pemberdayaan adalah suatu proses menolong kelompok atau individu yang dirugikan untuk bersaing secara lebih efektif dengan kepentingan-kepentingan lain, dengan menolong mereka untuk belajar dan menggunakan keterampilanketerampilan dalam melobi, menggunakan media, melakukan aksi politik, memahami bagaimana "memanfaatkan sistem" dan sebagainya. Dalam hal ini perspektif pluralis masuk didalam pemberdayaan suporter sepak bola hanya untuk proses menolong kelompok atau individu yang dirugikan. Seperti hanya memberikan pekerjaan untuk menjadi penjaga toko merchendaise khusus untuk sesama suporter yang sama saja. Tidak dibuka untuk umum.

\section{c. Perspektif Elite}

$$
\text { Dari perspektif ini, }
$$

pembedayaan membutuhkan lebih dari memiliki kemampuan berkompetisi untuk kekuasaan politik dengan 'memainkan permainan'; aturan main,bagaimana pun, telah ditetapkan oleh elite penguasa dan karena itu cenderung akan menguntungkan mereka. Perspektif elite ini tidak masuk ke dalam pemberdayaan di konteks suporter bola.

d. Perspektif Post-Struktural

Dari prespektif ini, pemberdayaan jadi suatu proses menantang dan mengubah wacana. Ia menekankan pengertian-pengertian subjektif manusia dan konstruksi pandangan dunia mereka, dan menunjuk kepada kebutuhan untuk mendekonstruksi pengertian-pengertian ini dan pembentukan suatu kosa kata alternatif untuk pemberdayaan. Prespektif post-struktural dengan demikian menekankan pengertian, analisis, dekonstruksi, pendidikan dan partisipasi dalam wacana-wacana kekuasaan, dan melihat sesuatu konsentrasi pada aksi saja sebagai tidak mencukupi.

Dalam hal ini, pemberdayaan yang dilakukan suporter sepak bola tidak mengalami post struktural. Karena mereka tidak mendekonstruksi hasil dari pemberdayaannya.

Seperti yang dikatakan oleh Dimas Maulana sebagai pengelola store online :

"tidak ada pelatihan yang diberikan. Jika pun ada ada pelatihan dari dinas, kurang menarik. Misalnya pelatihan marketting yang terlihat kuno."

Tidak ada pelatihan sama sekali yang diberikan untuk menghasilkan atau pun mengelola. Karena pelatihan yang sudah kuno sehingga tidak menarik lagi untuk minat para pengelola store online tersebut. Dari pihak menejemen pun juga tidak ada pelatihan yang diberikan.

"dari pihak menejemen sendiri pun tidak ada pelatihan. Karena mereka belum memiliki keterlibatan untuk mengumpulkan semua penggiat merchendaise." 
Berarti memang sudah jelas bahwa sama sekali tidak ada pelatihan yang diberikan agar mereka mampu bersaing dibidang produksi. Mereka mengandalkan keahlian masing-masing individunya. Dalam hal ini, pemberdayaan hanya masuk kedalam memperdayakan seseorang untuk menjadi pegawai dan tidak ada pelatihan yang diberikan. Tidak ada keterlibatan khusus dari luar untuk membantu proses pemberdayaan selama ini.

Sudah jelas selama ini para pekerja dari semua store online maupun store yang sudah ada tempatnya sendiri di konteks Yogyakarta ini mereka tidak diberikan pelatihan dari pihak menejemen maupun pihak yang terkait dengan hal ini. Sehingga store mereka hanya sebagai wadah untuk menampung hasil-hasil pembuatan dari masing-masing individu. Untuk dua klub yang ada didalam skripsi ini, keduanya tidak ada pelatihan untuk memperdayakan seseorang agar menjadi daya atau menghasilkan sesuatu.

PSS Sleman,

Sembada apparel merupakan store

Vikar sebagai bagian dari suporter yang ikut mengelola store mengatakan bahwa :

"kita hanya memperkerjakan pegawai dari suporter sendiri. Kita tidak membuka untuk umum karena kita memberikan pekerjaan untuk para suporter yang membutuhkan pekerjaan tetapi tetap tidak asal-asalan menerima pegawai walaupun suporter sendiri. Semua juga ada sop-nya."

Berarti pengelola store ini memberikan pekerjaan hanya untuk suporter sendiri. Karena pada dasarnya jumlah suporter sendiri lebih banyak sehingga mampu memberikan kesempatan agar mereka mendapatkan pekerjaan. Sejumlah merhcendaise yang ada di store online maupun toko-toko mereka dapatkan dari hasil produksi sendiri dan kemudian dititipkan ke store-store yang ada. Dari situlah penghasilan yang didapat dalam penjualan merchendaise atau jearsy-jearsy. Hasil penjualan diberikan untuk membantu keuangan club sepak bola masing-masing dan dapat menambah anggaran club sepak bola tersebut.
Curva Sud Shop yang lebih dikenal dengan CSS merupakan store atau toko yang menjual semua merchendaise untuk para suporter PSS Sleman. bahwa :

Seperti yang diutarakan Vikar

"kita dari store sendiri mampu membantu biaya oprasional untuk pihak menejemen dan tiap tahun dapat membantu memberikan bantuan dana."

Selama ini hasil pemberdayaan sangat membantu club untuk pengembangan club. Karena dari situ juga club dapat membiayai pemain-pemainnya dan memberikan kontribusi yang memuaskan. Kontribusi yang diberikan tidak hanya lewat hasil penjualan tiap masing-masing store tetapi juga dari hasil penjualan tiket. Dari situlah dapat menghidupi para pemainpemainnya selama ini. Dapat disimpulkan bahwa pemberdayaan dalam suporter sepak bola ini tidak ada pelatihan dari pihak terkait atau pihak menejemen sendiri karena mereka sudah memperkerjakan orang-orang yang sudah berpengalaman pada bidangnya masing-masing dan membuka kesempatan untuk memberikan wadah bagi mereka yang memproduksi sendiri.

\section{Kesimpulan}

Suporter sepak bola adalah
seseorang atau kerumunan yang memberikan dukungan. Untuk menjadi suporter sepak bola tidak ada persyaratan khusus. Pastinya datang menonton secara langsung atau tidak langsung. Pada dasarnya semua suporter itu tidak ada yang baik atau pun buruk. Semua suporter sama saja, kembali ke pribadi masing-masing akan menjadi suporter seperti apa nanti mereka. Pandangan masyarakat untuk menilai suporter bola sebenarnya sangat penting karena dapat mencerminkan seperti apa suporter bola nantinya. Ketika mereka sebagai suporter bola melakukan kericuhan atau kekerasan, tidak ada masyarakat yang menilai bahwa mereka adalah suporter yang baik. Para suporter bola berbondongbondong membuktikan bahwa mereka tidak hanya dicap sebagai suporter yang anarkis tapi mereka juga berupaya untuk menjadi 
suporter yang peduli terhadap sekelilingnya. Peduli terhadap sesama umat manusia kini mereka mulai membuktikan dengan tindakan sosial. Tindakan yang berdampak positif untuk para suporter sepak bola.

Seiring dengan perkembangan jaman, suporter sepak bola juga mampu bersaing dalam hal bisnis. Mereka membuka toko-toko merchendaise secara online mau pun tidak online. Mereka menjual tidak hanya untuk para suporter saja. Akan tetapi mereka menjual untuk umum. Harga yang diberikan cukup terjangkau bagi penggemar sepak bola. Harga mahal untuk kwalitas terbaik dan harga yang terjangkau untuk kwalitas yang tidak akan merugikan. Karena untuk sebagian suporter beranggapan bahwa mempunyai atribut itu perlu karena untuk identitas diri walaupun hanya memakai salah satu atribut saja.

\section{Daftar Pustaka.}

Buku.

Basrowi. 2005. Pengantar Sosiologi, Ghalia Indonesia

Beilharz, Peter, "Teori Teori Sosial", Juni 2002. PUSTAKA PELAJAR

Chols, J. M dan Hassan, S.. Kamus Bahasa Inggris - Bahasa Indonesia. (Jakarta: Gramedia,1988)

Ife, Jim dan Tesoriero, "Community Development : $\quad$ Alternatif Pengembangan Masyarakat di Era Globalisasi”, Pustaka Pelajar

Jezek, Geno. 2006. History of Soccer

Moelong, Lexy J. Metodologi Penelitian Kualitatif, (Bandung : Remaja Rosdakarya, 2000)

Soeprapto, SU, "Materi Kuliah Sosiologi Hukum (Yogyakarta 2010)"

Sugiyono. 2015. Metode Penelitian Kuantitatif, Kualitatif, dan R\&D”, Alfabeta cv

Suseno, Franz, Magnis, PEMIKIRAN KARL MARX (Dari Sosialisme Utopis ke Perselisihan Revisionisme) hal 241, "Theimer 1976, Kolakowski 1977 II dan Vranicki 1972 I"

\section{Web dan Blog}

Ariani, Irene, "Pentingnya Solidaritas dalam Kehidupan Manusia,"4 Januari 2013 diakses 5 Mei 2017 melalui www.kompasiana.com/ireneariani/penti ngnya-solidaritas-dalam-kehidupanmanusia_551b6fe2a33311b128b65970

Cangkallaxcorporation.blogspot.co.id, "Suporter Sepakbola Paling Kreatif di Indonesia", 14 Oktober 2013 diakses 15 April 2017 melalui http://cangkallaxcorporation.blogspot.co.id/2013/10/7suporter-sepak-bola-paling-kreatif$\underline{\text { di.html }}$

Huki, Luci, "Pengertian Kelompok Sosial", 29 Maret 2016 diakses 13 Juni 2017 melalui

http://anen9.blogspot.co.id/2016/03/pen gertian-kelompok-sosial.html

Ibrahim, Adzikra, "Pengertian Komunitas Manfaat Komunitas dan Beberapa Pertimbangan dalam Pembentukan Komunitas" diakses 13 Juni 2017 melalui

https://pengertiandefinisi.com/pengertia n-komunitas-manfaat-komunitas-danbeberapa-pertimbangan-dalampembentukan-komunitas/

Kamusbahasaindonesia.org diakses 6 Juni 2017 melalui https://kbbi.web.id/

Prasetyo, Galih, "Kreatifitas Edukatif Ekonomi Kreatif Suporter", 24 Maret 2017 diakses 5 Mei 2017 melalui www.indosport.com/sepakbola/2017032 4/mengajak-bekraf-berperan-dipemberdayaan-suporter/kreatifitasedukatif-ekonomi-kreatif-suporter

Subroto, Hadi, "Perilaku Sosial Suporter Sepakbola", 22 Februari 2011 diakses 8 November $2017 \quad$ melalui www.kompasiana.com/hadimenulis/peri laku-sosial-suportersepakbola 55008730a $333115263511 \mathrm{~d} 2$ $\underline{3}$

http://bcsxpss.com/post/news/2018-04-03/sinaubareng-cak-nun diakses pada 8 Juni 2018)

Artikel dan Jurnal. 
Asyroful Huda, "Profil PSIM Yogyakarta, Daftar Squad Pemain dan Sejarah PSIM, " 11 Juni 2017 diakses 25 Januari 2018 melalui https://sepakbolalokal.com/ligaindonesia /profil-psim-yogyakarta-daftar-skuadpemain-dan-sejarah-psim.html

Fandhybp, "Profil PSS Sleman, Daftar Squad Pemain dan Sejarah PSS", Juni 6, 2017 diakses 25 Januari 2018 melalui https://sepakbolalokal.com/ligaindonesia /profil-pss-sleman-daftar-skuad-pemaindan-sejarah-pss.html

Febriani, Putri, 2013. "BAB III Metode Penelitian" diakses 29 Januari 2018 melalui eprints.undip.ac.id /40789/3/BAB_III_METODE.pdf

Yanuar, "Buntut Kematian Suporter PSCS, Komdis Hukum PSS Sleman,"15 Oktober 2014 diakses 12 April 2017 melalui

http://bola.liputan6.com/read/2119144/b untut-kematian-suporter-pscs-komdishukum-pss-sleman

Handoko, Ariftri \& $\quad$ Andrianto,
Sonny/2006/,"Hubungan
Fanatisme Positif terhadap Klub
Sepakbola dengan Motivasi menjadi
Suporter" diakses 20 Januari 2018
melalui
http://eprints.ums.ac.id/26541/13/NASK
AH_PUBLIKASI.pdf

Hutagalang, Daniel,"Kaum Anarkis dan Pejuangan Demokratik Baru", april 2007 diakses 20 Januari 2018 melalui www.researchgate.net/publication/2879 96784_Kaum_Anarkis_dan_Pejuangan_ Demokratik_Baru

Mafiadoc.com," BAB V Kelompok Sosial 5.1 Pengantar Sosiologi.pdf" diakses 13 Juni 2017 melalui https://mafiadoc.com/bab-v-kelompoksosial-51-pengantar-dalam-sosiologi59f5a91a1723dd193a043c58.html

Makruf, Ilham, "Anarkisme Yang Dilakukan Oleh Suporter Sepakbola Di Indonesia", 31 Desember 2015 di akses 25 Januari 2018 melalui www.scribd.com/doc/294367565/Anark isme-Yang-Dilakukan-Oleh-SuporterSepakbola-Di-Indonesia

Raharjo, Edzan, Detiknews, "Bentrokan Suporter di Laga PSS Sleman VS PSIM Yogya, Belasan Orang Terluka", 29 April 2014 diakses 12 April 2017 melalui https://news.detik.com/berita/2569156/bentr okan-suporter-di-laga-pss-sleman-vs-psimyogya-belasan-orang-terluka

Razak, Zulkifli, "PERKEMBANGAN TEORI SOSIAL (Menyongsong Era Postmoderinisme), CV Sah Media, Makasar 